\title{
HIV-1 Virologic Rebound Due to Coadministration of Divalent Cations and Bictegravir
}

Alex E. Rock · Patricia L. DeMarais - Pamala T. Vergara-Rodriguez •

Blake E. Max

Received: April 23, 2020 / Published online: July 4, 2020

(C) The Author(s) 2020

\section{ABSTRACT}

A potential drug-drug interaction exists between divalent and trivalent cations $\left(\mathrm{Ca}^{2+}\right.$, $\mathrm{Fe}^{3+}, \mathrm{Mg}^{2+}, \mathrm{Al}^{3+}, \mathrm{Zn}^{2+}$ ) and HIV-1 integrase strand transfer inhibitors (INSTIs). There are limited case reports describing the clinical significance of this potential interaction and none to our knowledge identifying zinc co-administration with INSTIs. In this report we present a patient taking bictegravir/emtricitabine/tenofovir alafenamide who became viremic after ingesting zinc and calcium supplements and later was able to obtain virologic re-suppression after discontinuing supplements. This case represents a potential significant drug interaction between a commonly prescribed antiretroviral drug class and readily available over-the-counter divalent cation products.

Alex E. Rock and Blake E. Max contributed equally to the work.

Digital Features To view digital features for this article go to https://doi.org/10.6084/m9.figshare.12357842.

A. E. Rock $(\varangle)$. B. E. Max

Department of Pharmacy Practice, University of Illinois at Chicago, Chicago, IL, USA

e-mail: arock3674@gmail.com

P. L. DeMarais · P. T. Vergara-Rodriguez - B. E. Max Ruth M. Rothstein CORE Center and Stroger

Hospital of Cook County Health, Chicago, IL, USA
Keywords: AIDS; Calcium; Divalent cations; Drug interaction; HIV; HIV integrase inhibitors; INSTI; Integrase strand transfer inhibitors; Zinc

\section{Key Summary Points}

\section{Why carry out this study?}

Integrase inhibitors, the newest class of antiretrovirals, are considered a part of first-line HIV therapy and commonly utilized. They are well tolerated and interact with very few other medications. However, a class drug-drug absorption interaction between integrase inhibitors and divalent cations is a notable exception.

We observed a case of HIV treatment failure secondary to high doses of concomitant zinc supplementation with Biktarvy. Zinc is often not mentioned as a divalent cation of concern in the literature or package inserts.

\section{What was learned from the study?}

It is possible to fail Biktarvy therapy if high enough doses of zinc are administered.

Diligent medication reconciliation, HIV and antiretroviral stewardship are important when assessing HIV treatment failure. 


\section{INTRODUCTION}

Integrase inhibitors (INSTIs) have become the preferred backbone for HIV treatment-naïve patients because they are well tolerated, highly effective and infrequently interact with other medications [1]. However, a potential drug-drug interaction exists between divalent and trivalent cations $\left(\mathrm{Ca}^{2+}, \mathrm{Fe}^{3+}, \mathrm{Mg}^{2+}, \mathrm{Al}^{3+}, \mathrm{Zn}^{2+}\right)$ and INSTIs. HIV-1 integrase enzyme has a catalytic site that coordinates two divalent magnesium cations essential for viral DNA integration [2]. Therefore, administration of divalent cations in the form of calcium, iron or magnesium supplements with INSTIs could result in a decrease in INSTI absorption from the gastrointestinal tract. Several studies have shown reduced serum concentrations of INSTIs when co-administered with divalent cations $[3,4]$.

\section{CASE REPORT}

We present a case of a HIV + person who became viremic after ingesting zinc and calcium supplements. This case report is in compliance with ethics guidelines and is based on previously conducted clinical studies and does not contain any studies with human participants or animals performed by any of the authors. A 42-year-old HIV-positive Hispanic male with a history of diabetes mellitus type II, hypertension and hyperlipidemia was admitted to John $\mathrm{H}$ Stroger Hospital for right foot pain and swelling. At the time of hospital admission, the patient was prescribed atorvastatin $80 \mathrm{mg}$ daily, amlodipine/benazepril $5 \mathrm{mg} / 40 \mathrm{mg}$ daily, bictegravir/emtricitabine/tenofovir alafenamide $50 \mathrm{mg} / 200 \mathrm{mg} / 25 \mathrm{mg}$ daily, fenofibrate $160 \mathrm{mg}$ daily, dulaglutide $0.75 \mathrm{mg}$ subcutaneous injection weekly, linagliptin $5 \mathrm{mg}$ daily, metformin $1000 \mathrm{mg}$ twice a day and insulin 70/30 35 units twice a day. Prior to admission the patient visited a naturalist located in his neighborhood to seek advice regarding his worsening diabetic foot complications. The naturalist recommended zinc tablets and a zinc solution that was provided by the naturalist from the clinic. The zinc tablets were manufactured by Nature's
Sunshine ${ }^{\circledR}$ and contained zinc $25 \mathrm{mg}$, calcium $45 \mathrm{mg}$ and phosphorus $35 \mathrm{mg} /$ tablet. The patient was instructed to take three tablets every $3 \mathrm{~h}$ while awake. The patient reported taking approximately 12 tablets/day for a daily dose of $300 \mathrm{mg}$ zinc, $540 \mathrm{mg}$ calcium and $420 \mathrm{mg}$ phosphorus and took a total of 150 tablets over approximately 2 weeks. The patient was also given a vial of zinc solution of unknown concentration and instructions to administer six drops in water and drink every $3 \mathrm{~h}$.

The patient was diagnosed HIV positive in February 2014 and had baseline HIV viral load $=371,691$ copies $/ \mathrm{ml}$ and CD4 + T-lymphocyte count $=279$ cells $/ \mathrm{ml}$. Antiretroviral therapy was started May 2014 and within 5 months the patient had HIV viral load $<200$ copies/ml. Despite poor diabetes control, HIV viral load remained undetectable (HIV viral load $<40$ copies $/ \mathrm{ml}$, except for one viral blip $=$ 61 copies/ml observed in January 2018) for the next 51 months and CD4 + T-lymphocytes ranged between 463 and 830 cells $/ \mathrm{ml}$. At the time of hospital admission routine laboratory tests were drawn, and the HIV viral load was 56,477 copies/ml and CD4 + T-lymphocytes $=537$ cells $/ \mathrm{ml}$. The patient reported excellent adherence to bictegravir/emtricitabine/tenofovir alafenamide as evidenced by his undetectable viral load for the past 51 months. During hospitalization the patient informed the medical team that he had been consuming the zinc tablets and zinc solution. Zinc was not administered during hospitalization, and the patient was educated about the possible drug interaction between zinc and his antiretroviral therapy. The patient was instructed to discontinue all forms of zinc supplements and bictegravir/emtricitabine/tenofovir alafenamide was continued. Laboratory tests were reassessed 1 month later after hospital discharge, and the HIV viral load returned to $<40$ copies/ml and has remained undetectable.

\section{DISCUSSION}

This case report highlights the potential interaction between divalent cations (both zinc and calcium) and bictegravir resulting in virologic 
Table 1 Package insert recommendations for INSTI-divalent cation drug interactions

\begin{tabular}{|c|c|c|c|}
\hline Medication & Brand & $\begin{array}{l}\text { Divalent cation } \\
\text { referenced }\end{array}$ & Administration advice \\
\hline \multirow[t]{2}{*}{ Bictegravir } & \multirow[t]{2}{*}{$\begin{array}{l}\text { Biktarvy (bictegravir, emtricitabine, } \\
\text { and tenofovir alafenamide) }\end{array}$} & $\mathrm{Mg}, \mathrm{Al}, \mathrm{Ca}$ & $\begin{array}{l}\text { Biktarvy can be taken under fasting } \\
\text { conditions } 2 \mathrm{~h} \text { before antacids containing } \mathrm{Al} / \\
\mathrm{Mg} \text { or calcium }\end{array}$ \\
\hline & & $\mathrm{Ca}, \mathrm{Fe}$ & $\begin{array}{l}\text { Biktarvy and supplements containing calcium or } \\
\text { iron can be taken together with food }\end{array}$ \\
\hline \multirow[t]{5}{*}{ Dolutegravir } & Tivicay (dolutegravir) & Polyvalent cations & $\begin{array}{l}\text { Tivicay should be administered } 2 \mathrm{~h} \text { before or } 6 \mathrm{~h} \\
\text { after taking medications containing polyvalent } \\
\text { cations }\end{array}$ \\
\hline & \multirow[t]{2}{*}{$\begin{array}{l}\text { Triumeq (dolutegravir, abacavir, } \\
\text { lamivudine) }\end{array}$} & Polyvalent cations & $\begin{array}{l}\text { Administer Triumeq } 2 \mathrm{~h} \text { before or } 6 \mathrm{~h} \text { after } \\
\text { taking medications containing polyvalent } \\
\text { cations }\end{array}$ \\
\hline & & $\mathrm{Ca}$ or $\mathrm{Fe}$ & $\begin{array}{l}\text { Alternatively, Triumeq and supplements } \\
\text { containing calcium or iron can be taken } \\
\text { together with food }\end{array}$ \\
\hline & \multirow[t]{2}{*}{ Dovato (dolutegravir, lamivudine) } & Polyvalent cations & $\begin{array}{l}\text { Administer Dovato } 2 \mathrm{~h} \text { before or } 6 \mathrm{~h} \text { after taking } \\
\text { medications containing polyvalent cations }\end{array}$ \\
\hline & & $\mathrm{Ca}$ or $\mathrm{Fe}$ & $\begin{array}{l}\text { Alternatively, Dovato and supplements } \\
\text { containing calcium or iron can be taken at the } \\
\text { same time }\end{array}$ \\
\hline \multirow[t]{2}{*}{ Elvitegravir } & $\begin{array}{l}\text { Stribild (elvitegravir, cobicistat, } \\
\text { emtricitabine, tenofovir } \\
\text { disoproxil fumarate) }\end{array}$ & $\begin{array}{l}\text { Antacids, e.g., } \\
\text { aluminum and } \\
\text { magnesium hydroxide }\end{array}$ & $\begin{array}{l}\text { Separate Stribild and antacid administration by } \\
\text { at least } 2 \mathrm{~h}\end{array}$ \\
\hline & $\begin{array}{l}\text { Genvoya (elvitegravir, cobicistat, } \\
\text { emtricitabine, tenofovir } \\
\text { alafenamide) }\end{array}$ & $\begin{array}{l}\text { Antacids, e.g., } \\
\text { aluminum and } \\
\text { magnesium hydroxide }\end{array}$ & $\begin{array}{l}\text { Separate Genvoya and antacid administration by } \\
\text { at least } 2 \mathrm{~h}\end{array}$ \\
\hline \multirow[t]{4}{*}{ Raltegravir } & \multirow[t]{2}{*}{$\begin{array}{l}\text { Isentress (raltegravir) (twice daily } \\
\text { dose) }\end{array}$} & $\begin{array}{l}\text { Aluminum and/or } \\
\text { magnesium- } \\
\text { containing antacids }\end{array}$ & $\begin{array}{l}\text { Co-administration or staggered administration is } \\
\text { not recommended }\end{array}$ \\
\hline & & $\begin{array}{l}\text { Calcium carbonate } \\
\text { antacid }\end{array}$ & No dose adjustment \\
\hline & \multirow[t]{2}{*}{$\begin{array}{l}\text { Isentress (raltegravir) HD (daily } \\
\text { dose) }\end{array}$} & $\begin{array}{l}\text { Aluminum and/or } \\
\text { magnesium- } \\
\text { containing antacids }\end{array}$ & $\begin{array}{l}\text { Co-administration or staggered administration is } \\
\text { not recommended }\end{array}$ \\
\hline & & $\begin{array}{l}\text { Calcium carbonate } \\
\text { antacid }\end{array}$ & Co-administration is not recommended \\
\hline
\end{tabular}


rebound. There are no case reports to our knowledge identifying an interaction specifically with zinc and a few case reports describing virologic rebound or treatment failure on INSTIbased regimens due to divalent cations [5]. Although the manufacturer prescribing information for INSTIs reference the interaction with divalent cations, they do not specifically mention zinc [6-12]. Also, drug-drug interaction web sites, including hiv-druginteractions.orgUniversity of Liverpool, other public HIV drug interaction databases and the Department of Health and Human Services HIV treatment guidelines do not identify zinc as a potential interacting medication [1, 6-12]. Table 1 illustrates the current manufacturer's recommendations regarding administration of divalent cations with INSTIs. These recommendations lack consistency and can be confusing for patients and healthcare providers to interpret.

Zinc is available over the counter and therefore available to persons living with HIV/ AIDS (PLWHA). Review of the natural medicines database found that zinc has been widely used for many conditions including a variety of infections. Some of the infections for which zinc has been claimed to improve symptoms are the common cold, influenza, upper respiratory infections, ear infections and urinary tract infections. Zinc is taken for non-infectious maladies including depression, diarrhea and muscle cramps among others. The evidence supporting zinc as an adjunct in the setting or either viral or bacterial infections has been conflicting. Zinc studies that resulted in a benefit utilized doses ranging from 9 to $24 \mathrm{mg}$ lozenges every $2 \mathrm{~h}$ while awake while other trials showed no benefit [13].

Over the last 2 decades there have been many trials to determine if zinc has any clinical benefit for the treatment of HIV and its associated syndromes. Zinc has been studied as a treatment modality for antiretroviral-induced diarrhea, appetite stimulation and an adjunct in viral suppression. A literature review found numerous studies that reported an inconclusive effect of zinc on CD4 + T-lymphocyte recovery in PLWHA [14-22]. However, we also found multiple studies that promoted the benefit of zinc in PLWHA [23-27]. Another area of research is the anti-inflammatory effects of zinc and how this property may be beneficial to PLWHA who have cardiovascular disease $[28,29]$. There is a need for further investigation into the possible clinical benefits of zinc and if there is any potential benefit for PLWHA. Although zinc has not shown a clear specific benefit in PLWHA, some patients may be purchasing zinc over the counter and self-medicating for a variety of ailments. The over-thecounter availability of zinc and the proposed variety of ailments zinc can supposedly treat make it a concern for INSTI drug interactions.

\section{CONCLUSION}

This case represents a potential significant drug interaction between a commonly prescribed antiretroviral and a readily available over-thecounter product. This interaction is not necessarily specific to bictegravir and zinc products, but to all INSTIs that have the potential to chelate divalent cations. This event also highlights the importance of medication reconciliation including over-the-counter products, herbal supplements and medications given to patients by non-traditional medical providers. Additionally, gaps in common HIV drug interaction resources have been identified in the context that a known divalent cation (zinc) is missing from the INSTI/cation drug interaction recommendations. When prescribed antiretroviral therapy, PLWHA need to be educated about possible drug interactions regarding concomitant therapy and the myriad over-thecounter products.

\section{ACKNOWLEDGEMENTS}

The authors thank the Ruth M. Rothstein CORE Center and the John H Stroger Hospital of Cook County for allowing us to participate in the medical care for this patient. Additionally, we thank both the inpatient HIV pharmacist Robert Glowacki, PharmD, and Gerardo Hernandez (Spanish language interpreter) for their assistance in obtaining information for this manuscript. 
Funding. No funding or sponsorship was received for the study or publication of this article.

Authorship. All named authors meet the International Committee of Medical Journal Editors (ICMJE) criteria for authorship for this article, take responsibility for the integrity of the work as a whole, and have given their approval for this version to be published.

Authorship Contributions. AR, PharmDmanuscript writer, researcher, direct patient care; PDM, MD—direct patient care, reviewed manuscript; PV-R, MD-direct patient care, reviewed manuscript; Blake Max, PharmD-direct patient care, reviewed manuscript.

Disclosures. Alex Rock, Patricia DeMarais, Pamala Vergara-Rodriguez and Blake Max have no competing interests.

Compliance with Ethics Guidelines. In compliance with ethics guidelines this article is based on previously conducted studies and does not contain any studies with human participants or animals performed by any of the authors.

Open Access. This article is licensed under a Creative Commons Attribution-NonCommercial 4.0 International License, which permits any non-commercial use, sharing, adaptation, distribution and reproduction in any medium or format, as long as you give appropriate credit to the original author(s) and the source, provide a link to the Creative Commons licence, and indicate if changes were made. The images or other third party material in this article are included in the article's Creative Commons licence, unless indicated otherwise in a credit line to the material. If material is not included in the article's Creative Commons licence and your intended use is not permitted by statutory regulation or exceeds the permitted use, you will need to obtain permission directly from the copyright holder. To view a copy of this licence, visit http://creativecommons.org/licenses/by$\mathrm{nc} / 4.0 /$.

\section{REFERENCES}

1. Panel on Antiretroviral Guidelines for Adults and Adolescents. Guidelines for the Use of Antiretroviral Agents in Adults and Adolescents with HIV. Department of Health and Human Services. Available at http://www.aidsinfo.nih.gov/ContentFiles/ AdultandAdolescentGL.pdf. Accessed 15 May 2020 [Table 6a, Table 21d].

2. Hajimahdi Z, Zarghi A. Progress in HIV-1 integrase inhibitors: a review of their chemical structure diversity. Iran J Pharm Res. 2016;15(4):595-628.

3. Song I, Borland J, Arya N, Wynne B, Piscitelli S. Pharmacokinetics of dolutegravir when administered with mineral supplements in healthy adult subjects. J Clin Pharmacol. 2015;55(5):490-6.

4. Krishna R, East L, Larson P, et al. Effect of metalcation antacids on the pharmacokinetics of $1200 \mathrm{mg}$ raltegravir. J Pharm Pharmacol. 2016;68(11):1359-65.

5. Forst TM, Dinges WL. Coadministration of divalent cation mineral supplements causes CART virologic failure and hiv mutagenesis: a Case Study. Clin J HIV AIDS. 2018;2(1):26-7.

6. Tivicay (dolutegravir) [package insert]. Research Triangle Park, NC: GlaxoSmithKline; August 2013.

7. Triumeq (dolutegravir/abacavir/lamivudine) [package insert]. Research Triangle Park, NC: GlaxoSmithKline; August 2014.

8. Dovato (dolutegravir/lamivudine) [package insert]. Research Triangle Park, NC: GlaxoSmithKline; April 2019.

9. Stribild (elvitegravir, cobicistat, emtricitabine, tenofovir desoproxil fumarate) [package insert]. Foster City, CA: Gilead Sciences, Inc.; August 2017.

10. Genvoya (elvitegravir. cobicistat, emtricitabine, tenofovir alafenamide) [package insert]. Foster City, CA: Gilead Sciences, Inc.; December 2016.

11. Biktarvy (bictegravir, emtricitabine, tenofovir alafenamide) [package insert]. Foster City, CA: Gilead Sciences, Inc; February 2018.

12. Isentress (raltegravir) [package insert]. Whitehouse Station, NJ: Merck \& Co., Inc.; August 2013.

13. Zinc. In: Natural Medicines Comprehensive Database. Somerville, MA: Natural Standard. [Published 2020]. https://naturalmedicines. therapeuticresearch.com/databases/food,-herbssupplements/professional.aspx?productid $=982$. Accessed 20 Jan 2020 
14. Lodha $\mathrm{R}$, Shah $\mathrm{N}$, Mohari N, et al. Immunologic effect of zinc supplementation in HIV-infected children receiving highly active antiretroviral therapy: a randomized, double-blind, placebo-controlled trial. J Acquir Immune Defic Syndr. 2014;66(4):386-92.

15. Motswagole BS, Mongwaketse TC, Mokotedi M, et al. The efficacy of micronutrient-fortified sorghum meal in improving the immune status of HIV-positive adults. Ann Nutr Metab. 2013;62(4): 323-30.

16. Ndeezi G, Tylleskar T, Ndugwa CM, Tumwine JK. Effect of multiple micronutrient supplementation on survival of HIV-infected children in Uganda: a randomized, controlled trial. J Int AIDS Soc. 2010;13:18.

17. Sundaram M, Saghayam S, Priya B, et al. Changes in antioxidant profile among HIV-infected individuals on generic highly active antiretroviral therapy in southern India. Int J Infect Dis. 2008;12(6):e61-6.

18. Green JA, Lewin SR, Wightman F, Lee M, Ravindran TS, Paton NI. A randomised controlled trial of oral zinc on the immune response to tuberculosis in HIV-infected patients. Int $J$ Tuberc Lung Dis. 2005;9(12):1378-84.

19. Villamor E, Aboud S, Koulinska IN, et al. Zinc supplementation to HIV-1-infected pregnant women: effects on maternal anthropometry, viral load, and early mother-to-child transmission. Eur J Clin Nutr. 2006;60(7):862-9.

20. Bobat R, Coovadia H, Stephen C, et al. Safety and efficacy of zinc supplementation for children with HIV-1 infection in South Africa: a randomised double-blind placebo-controlled trial. Lancet. 2005;366(9500):1862-7.

21. Fawzi WW, Villamor E, Msamanga GI, et al. Trial of zinc supplements in relation to pregnancy outcomes, hematologic indicators, and $\mathrm{T}$ cell counts among HIV-1-infected women in Tanzania. Am J Clin Nutr. 2005;81(1):161-7.
22. Reich EN, Church JA. Oral zinc supplementation in the treatment of HIV-infected children. Pediatr AIDS HIV Infect. 1994;5(6):357-60.

23. Baum MK, Lai S, Sales S, Page JB, Campa A. Randomized, controlled clinical trial of zinc supplementation to prevent immunological failure in HIV-infected adults. Clin Infect Dis. 2010;50(12): 1653-60.

24. Zhao F, Wang Z, Li WJ. Impact of micronutrients on immunocyte and microelements status among people living with HIV. Zhonghua Liu Xing Bing Xue Za Zhi. 2009;30(5):452-4.

25. Asdamongkol N, Phanachet P, Sungkanuparph S. Low plasma zinc levels and immunological responses to zinc supplementation in HIV-infected patients with immunological discordance after antiretroviral therapy. Jpn J Infect Dis. 2013;66(6): 469-74.

26. Moyle G, Else L, Jackson A, et al. Coadministration of atazanavir-ritonavir and zinc sulfate: impact on hyperbilirubinemia and pharmacokinetics. Antimicrob Agents Chemother. 2013;57(8):3640-4.

27. Bunupuradah T, Ubolyam S, Hansudewechakul R, et al. Correlation of selenium and zinc levels to antiretroviral treatment outcomes in Thai HIV-infected children without severe HIV symptoms. Eur J Clin Nutr. 2012;66(8):900-5.

28. Gnatienko N, Freiberg MS, Blokhina E, et al. Design of a randomized controlled trial of zinc supplementation to improve markers of mortality and HIV disease progression in HIV-positive drinkers in St. Petersburg, Russia. HIV Clin Trials. 2018;19(3): 101-11.

29. Jung S, Kim MK, Choi BY. The relationship between zinc status and inflammatory marker levels in rural Korean adults aged 40 and older. PLoS One. 2015;10(6):e0130016. 